\title{
Evaluation of new insecticide molecules for their effectiveness in the management of sugarcane early shoot borer, Chilo infuscatellus (Snellen)
}

\author{
H.G. Umashankar ${ }^{1 *}$, V.N. Patel ${ }^{2}$, T. Nagaraja ${ }^{2}$, L. Vijaykumar ${ }^{3}$ and S. Sugeetha ${ }^{3}$ \\ ${ }^{1}$ Department of Agricultural Entomology, University of Agricultural Sciences Bengaluru, (Karnataka), INDIA \\ ${ }^{2}$ AICRP on Sugarcane, Zonal Agricultural Research Station, VC Farm Mandya-571405 (Karnataka), INDIA \\ ${ }^{3}$ College of Agriculture, VC Farm Mandya-571405, Karnataka, INDIA \\ *Corresponding author. Email: umashankarhg21@gmail.com
}

Received: June 9, 2017; Revised received: November 4, 2017; Accepted: February 17, 2018

\begin{abstract}
An experiment was conducted at Zonal Agricultural Research Station, V.C farm, Mandya (Karnataka), India during 2015, to assess the chemical control of sugarcane early shoot borer (Chilo infuscatellus). Nine insecticides namely, Fipronil 0.3G, Chlorantraniliprole 0.4G, Chlorantraniliprole 18.5 SC, Spinosad 45SC, Flubendiamide 39.35SC, Cartap hydrochloride 4G, Phorate 10G, Carbofuran 3G, Chlorpyriphos 20EC, and compared with untreated (Check plot)using randomized block design with three replications. Significant differences were noticed among the treatments. Chlorantraniliprole $0.4 \mathrm{G}$ recorded lowest cumulative incidence $(2.79 \%)$ and highest per cent reduction over the control (85.78 \%) which was followed by Cartap hydrochloride $4 \mathrm{G}(5.37 \%$ and $72.65 \%)$, Chlorantraniliprole 18.5 SC (5.95\% and $75.62 \%)$, Flubendiamide 39.35 SC $(6.64 \%$ and $66.19 \%)$ and Fipronil $0.3 \mathrm{G}$ $(6.83 \%$ and $65.22 \%)$ were found significantly superior in reducing the cumulative incidence of $C$. infuscatellus. In Co 86032 Cartap hydrochloride $4 G$ was found to be the best insecticide in getting a highest cost benefit ratio (1:12.39). Other insecticides such as Fipronil 0.3G (1:8.84), Chlorantraniliprole 0.4G (1:6.96), Flubendiamide 39.35SC (1:5.42) and Spinosad 45SC (1:4.16) have also recorded better cost benefit ratio. Since Cartap hydrochloride $4 \mathrm{G}$ does not have crop label so we can recommend Fipronil $0.3 \mathrm{G}$ or Chlorantraniliprole $0.4 \mathrm{G}$ for the management of sugarcane early shoot borer.
\end{abstract}

Keywords: Cartap hydrochloride 4G, Chilo infuscatellus, Chlorantraniliprole 0.4G, Cumulative incidence and Early shoot borer

\section{INTRODUCTION}

Sugarcane (Saccharum officinarum L.) is an important commercial crop that is cultivated in more than seventy countries between $40^{\circ} \mathrm{N}$ and $32^{\circ} 5^{\prime} \mathrm{S}$. It is also an important cash crop of India. India ranks first in the world in the area under sugarcane cultivation and ranks fifth in the world in terms of sugar production. In India, sugarcane occupies an area of $5.01 \mathrm{~m}$ ha and produces $338.96 \mathrm{~m}$ tones of cane with an average productivity of 66.99 tones $^{-1} \mathrm{~h}^{-1}$ (Anonymous, 2015). The major challenges faced by the crop are lower than average per area production, low sugar recovery and higher cost of production. The production and productivity of the sugarcane are affected by many factors viz, soil type, selections of variety, fertilizer management, irrigation management and damage caused by pests. Sugarcane is attacked by insects. However, 15 pests are reported to cause considerable loss in yield. The early shoot borer, top shoot borer, internode borer, white grub, sugarcane pyrilla, white Woolly aphid, Scale insect and Termites are a major pest of sugarcane, but the early shoot borer is worst pest which is responsible for severe damage in early growth stage and yield loss.
The shoot Borer, Chilo infuscatellus (Snellan) (Pyralidae; Lepidoptera) cause economic losses (Avasthy and Tiwari, 1986) from 22-23 per cent in yield, 12 per cent in sugar recovery and 27 per cent in Jaggary. The pest is mainly injuries to young cane up to 8 weeks after planting. The caterpillars after hatch out from eggs get scattered and enter into the young shoots by making the holes just above ground levels and tunnels downwards. The central shoot dries up causing 'dead hearts'. It is a characteristic sign of the presence of the pest within the plants. The dead heart can be easily pulled out of the central shoot, roots inside the stem and emits an offensive smell of being pulled out(Patil and Hapse,1981). Several control methods have been evaluated from time to time. Among the different management strategies, the use of chemicals is one of the important components of IPM. From time to time several insecticides were tried and recommended for the management of early shoot borer. In spite of that, the problem of early shoot borer still persists. Therefore, the efforts are made to find out the insecticides for management of early shoot borer in sugarcane. 


\section{MATERIALS AND METHODS}

To evaluate the efficacy of new insecticide molecules an experiment was laid out in Randomized Complete Block Design (RCBD) with ten treatments (Table 1), including an untreated control and replicated thrice at ZARS, V.C., Farm, Mandya. The experiment was conducted on 18-05-15 with commercial sugarcane (Saccharum officinarum L.) variety, Co 86032. Each treatment was having six rows of five meter length with 0.9 meter row to row spacing. Application of insecticides was done as mentioned (Table 3). The observation on germination percentage at $30 \mathrm{DAP}$ and the incidence of early shoot borer at 30, 60, 90, 120 DAP were recorded, and the mean per cent pest incidence was worked out.At the end of 12 months, the crop was harvested, gross and net plot yield were recorded.

A number of dead hearts caused by early shoot borer (Chilo infuscatellus) out of the total number of tillers observed in all the entries at 30, 60, 90 and 120 days after planting (DAP) was recorded. After each count, the dead hearts were pulled out to avoid counting them later on.The per cent incidence ofearly shoot borer (ESB), Chilo infuscatellus was calculated by using the formula

Per cent incidence $=$ Number of dead hearts $/$ Total number of tillers $\times 100$

The cumulative per cent incidence was worked out by relating the progressive total of infested tillers (deadhearts) in proportion to the total number of tillers (Sithanantham, 1973) at 120 DAP.The data on per cent pest incidence was processed by using suitable transformation and, the data on pest incidence of each treatment were subjected to ANOVA (Gomez and Gomez, 1984; Hosmand, 1988) and means were separated by Tukey's HSD (Tukey, 1965). The yield data were subjected to statistical analysis for interpretation and cost economics of each treatment was worked out. In order to find out the benefit cost analysis of the treatment versus control, total yield was converted into yield/ha. The yield /ha was then multiplied with a unit price of the cane to get a gross income of the treatment. The incremental returns were obtained by subtracting the gross income from the check plot income. The cost of treatment was calculated on a hectare basis. The net benefit was obtained by subtracting the total cost of the treatment from the gross income of the treatment. Cost benefit ratio was calculated through gross income divided by total cost. Greater the C: B ratio indicates the efficiency of the treatment.

\section{RESULTS AND DISCUSSION}

The cumulative per cent incidence of early shoot borer in different treatments varied from 2.79 to 15.33 whereas it was 19.65 in the untreated control. The lowest cumulative per cent incidence (2.79) of ESB was

Table 1. Treatment details of insecticides used in the management of $C$. infuscatellus in Sugarcane.

\begin{tabular}{llll}
\hline Treatment & Chemicals & g/ml a.i./ha & Time of application \\
\hline $\mathrm{T}_{1}$ & Fipronil 0.3G & 0.075 & At planting \& 60 DAS \\
$\mathrm{T}_{2}$ & Chlorantraniliprole $0.4 \mathrm{G}$ & 0.09 & At planting \& 60 DAS \\
$\mathrm{T}_{3}$ & Chlorantraniliprole $18.5 \mathrm{SC}$ & 69.4 & At 30 \& 60 DAS \\
$\mathrm{T}_{4}$ & Spinosad 45SC & 40.5 & At 30 \& 60 DAS \\
$\mathrm{T}_{5}$ & Flubendiamide 39.35SC & 49.19 & At 30 \& 60 DAS \\
$\mathrm{T}_{6}$ & Cartap hydrochloride 4G & 0.50 & At planting \& 60 DAS \\
$\mathrm{T}_{7}$ & Phorate 10G & 1.50 & At planting \& 60 DAS \\
$\mathrm{T}_{8}$ & Carbofuran 3G & 1.00 & At planting \& 60 DAS \\
$\mathrm{T}_{9}$ & Chlorpyriphos 20EC & 300 & At 30 \& 60 DAS \\
$\mathrm{T}_{10}$ & Control & - & - \\
\hline
\end{tabular}

Table 2. Bioefficacy of insecticide against early shoot borer in variety Co 86032 at Zonal Agricultural Research Station V. C. Farm, Mandya.

\begin{tabular}{|c|c|c|c|c|c|c|}
\hline S. $\mathbf{N}$. & Treatment & Germination \% & g/ml/a.i/ha & $\begin{array}{l}\text { Cumulative inci- } \\
\text { dence of ESB }(\%)\end{array}$ & $\begin{array}{l}\text { Per cent reduction } \\
\text { over the control }\end{array}$ & $\begin{array}{l}\text { Cane yield } \\
\text { (t/ha) }\end{array}$ \\
\hline $\mathrm{T}_{1}$ & Fipronil $0.3 \mathrm{G}$ & 76.89 & 0.075 & $6.83(25.99)^{\mathrm{abc}}$ & 65.22 & $77.45^{\mathrm{ab}}$ \\
\hline $\mathrm{T}_{2}$ & Chlorantraniliprole $0.4 \mathrm{G}$ & 78.89 & 0.09 & $2.79(16.14)^{\mathrm{a}}$ & 85.78 & $87.51^{\mathrm{a}}$ \\
\hline $\mathrm{T}_{3}$ & Chlorantraniliprole $18.5 \mathrm{SC}$ & 74.11 & 69.4 & $5.95(24.28)^{\mathrm{ab}}$ & 69.72 & $75.62^{\mathrm{abc}}$ \\
\hline $\mathrm{T}_{4}$ & Spinosad 45SC & 69.78 & 40.5 & $7.78(27.53) b c$ & 60.39 & $68.77^{\mathrm{bcd}}$ \\
\hline $\mathrm{T}_{5}$ & Flubendiamide $39.35 \mathrm{SC}$ & 71.11 & 49.19 & $6.64(25.64)^{\mathrm{abc}}$ & 66.19 & $74.48^{a b c}$ \\
\hline $\mathrm{T}_{6}$ & Cartap hydrochloride $4 \mathrm{G}$ & 75.67 & 0.50 & $5.37(22.71)^{a b}$ & 72.65 & $74.16^{\mathrm{abc}}$ \\
\hline $\mathrm{T}_{7}$ & Phorate $10 \mathrm{G}$ & 67.00 & 1.50 & $12.45(35.10)^{\text {cde }}$ & 36.64 & $62.07^{\mathrm{cd}}$ \\
\hline $\mathrm{T}_{8}$ & Carbofuran 3G & 69.56 & 1.00 & $8.69(29.36)^{\mathrm{bcd}}$ & 55.77 & $66.17^{\mathrm{bcd}}$ \\
\hline $\mathrm{T}_{9}$ & Chlorpyriphos 20EC & 58.89 & 300 & $15.33(39.03)^{\mathrm{de}}$ & 21.98 & $62.23^{\mathrm{cd}}$ \\
\hline $\mathrm{T}_{10}$ & Control & 70.11 & & $19.65(44.46)^{\mathrm{e}}$ & & $58.67^{\mathrm{d}}$ \\
\hline \multicolumn{2}{|l|}{$\mathrm{SEm} \pm$} & NSC & & 0.70 & & 5.51 \\
\hline \multicolumn{2}{|c|}{$\mathrm{CD} @ \mathrm{P}=0.05$} & NS & & 2.00 & & 11.58 \\
\hline
\end{tabular}

NS: Non significant; Values in the column followed by common letters are non-significant at $\mathrm{p}=0.05$ as per Tuckey's HSD (Tukey, 1965). Figures in the paraentheses are arcsine $\sqrt{\mathrm{x}}$ transformed values 
H.G. Umashankar et al. / J. Appl. \& Nat. Sci. 10 (1): 434 - 438 (2018)

Table 3. Influence of different insecticides on quantitative yield parameters in Co 86032.

\begin{tabular}{|c|c|c|c|c|c|c|c|}
\hline SI. No. & Treatment & $\begin{array}{l}\text { Single } \\
\text { wt (kg) }\end{array}$ & cane & $\begin{array}{l}\text { Cane length } \\
\text { (m) }\end{array}$ & $\begin{array}{l}\text { Inter node } \\
\text { length }(\mathrm{cm})\end{array}$ & $\begin{array}{l}\text { Number of in- } \\
\text { ternodes }\end{array}$ & $\begin{array}{l}\begin{array}{l}\text { Cane girth } \\
(\mathrm{cm})\end{array} \\
\end{array}$ \\
\hline$\overline{\mathrm{T}_{1}}$ & Fipronil $0.3 \mathrm{G}$ & 1.53 & & 2.40 & 11.51 & 22.73 & 2.96 \\
\hline $\mathrm{T}_{2}$ & Chlorantraniliprole $0.4 \mathrm{G}$ & 1.55 & & 2.38 & 11.25 & 20.23 & 2.97 \\
\hline $\mathrm{T}_{3}$ & Chlorantraniliprole $18.5 \mathrm{SC}$ & 1.46 & & 2.15 & 10.86 & 19.30 & 3.03 \\
\hline $\mathrm{T}_{4}$ & Spinosad 45SC & 1.45 & & 2.17 & 10.32 & 19.47 & 2.72 \\
\hline $\mathrm{T}_{5}$ & Flubendiamide $39.35 \mathrm{SC}$ & 1.47 & & 2.19 & 10.75 & 19.72 & 2.78 \\
\hline $\mathrm{T}_{6}$ & Cartap hydrochloride $4 \mathrm{G}$ & 1.41 & & 2.24 & 10.78 & 19.97 & 3.03 \\
\hline $\mathrm{T}_{7}$ & Phorate 10G & 1.44 & & 2.20 & 10.53 & 19.40 & 2.96 \\
\hline $\mathrm{T}_{8}$ & Carbofuran $3 \mathrm{G}$ & 1.59 & & 2.22 & 10.52 & 19.99 & 2.92 \\
\hline $\mathrm{T}_{9}$ & Chlorpyriphos 20EC & 1.60 & & 2.23 & 10.23 & 20.28 & 2.98 \\
\hline $\mathrm{T}_{10}$ & Control & 1.40 & & 2.13 & 10.33 & 19.00 & 2.77 \\
\hline \multicolumn{2}{|c|}{$\begin{array}{l}\mathrm{SEm} \pm \\
\mathrm{CD} @ \mathrm{P}=0.05\end{array}$} & NS & & NS & NS & NS & NS \\
\hline
\end{tabular}

NS: Non significant; Values in the column followed by common letters are non-significant at $\mathrm{p}=0.05$ as per Tuckey's HSD (Tukey, 1965).

Table 4. Influence of different insecticides on the quality parameters in CO 86032.

\begin{tabular}{|c|c|c|c|c|c|}
\hline Sl. No. & Treatment & Brix \% & Sucrose \% & Purity \% & CCS\% \\
\hline$\overline{\mathrm{T}_{1}}$ & Fipronil $0.3 \mathrm{G}$ & 21.23 & 20.46 & 96.95 & 14.89 \\
\hline $\mathrm{T}_{2}$ & Chlorantraniliprole $0.4 \mathrm{G}$ & 21.87 & 20.66 & 95.92 & 14.72 \\
\hline $\mathrm{T}_{3}$ & Chlorantraniliprole $18.5 \mathrm{SC}$ & 21.27 & 20.51 & 96.45 & 14.92 \\
\hline $\mathrm{T}_{4}$ & Spinosad 45SC & 21.17 & 20.31 & 95.81 & 14.55 \\
\hline $\mathrm{T}_{5}$ & Flubendiamide $39.35 \mathrm{SC}$ & 20.97 & 20.09 & 96.57 & 14.47 \\
\hline $\mathrm{T}_{6}$ & Cartap hydrochloride $4 \mathrm{G}$ & 21.10 & 20.29 & 96.33 & 14.53 \\
\hline $\mathrm{T}_{7}$ & Phorate $10 \mathrm{G}$ & 21.00 & 20.32 & 95.87 & 14.20 \\
\hline $\mathrm{T}_{8}$ & Carbofuran $3 \mathrm{G}$ & 21.03 & 20.19 & 95.78 & 14.49 \\
\hline $\mathrm{T}_{9}$ & Chlorpyriphos 20EC & 20.83 & 20.13 & 95.58 & 14.31 \\
\hline $\mathrm{T}_{10}$ & Control & 20.10 & 20.00 & 94.00 & 14.03 \\
\hline \multicolumn{2}{|c|}{$\begin{array}{l}\mathrm{SEm} \pm \\
\mathrm{CD} @ \mathrm{P}=0.05\end{array}$} & NS & NS & NS & NS \\
\hline
\end{tabular}

NS: Non significant; CCS: Commercial cane sugar; Values in the column followed by common letters are non-significant at $\mathrm{p}=0.05$ as per Tuckey's HSD (Tukey, 1965).

recorded in Chlorantraniliprole $0.4 \mathrm{G}$ and Cartap hydrochloride $4 \mathrm{G}$ (5.37) and was significantly superior to rest of the treatments. This was followed by Chlorantraniliprole 18.5 SC (5.95), Flubendiamide 39.35SC (6.64), Fipronil 0.3G (6.83), Spinosad 45SC (7.78), Carbofuran 3G (8.69), Phorate 10G (12.45), and Chlorpyriphos 20EC (15.33) (Table 2). These results are in accordance with the observations of Pandey (2014), Anonymous (2015) and Padmasri et al. (2014) who reported that Chlorantraniliprole $0.4 \mathrm{G}$ and Chlorantraniliprole $18.5 \mathrm{SC}$ are the most effective insecticide against ESB; Bhawar et al. (2016) who reported that Flubendiamide 39.35SC and Cartap hydrochloride $4 \mathrm{G}$ were most effective in reducing the ESB attack.

The highest cane yield was recorded in Chlorantraniliprole $0.4 \mathrm{G} \quad((87.51 \mathrm{t} / \mathrm{ha})$ which was closely followed by Fipronil $0.3 \mathrm{G}$ (77.45 t/ha), Chlorantraniliprole 18.5 SC (75.62 t/ha), Flubendiamide 39.35SC (74.48 t/ha) and Cartap hydrochloride 4G (74.16 t/ha). These were followed by Spinosad 45SC (68.77 t/ha) and Carbofuran 3G (66.17). Relatively lower yields were recorded in Chlorpyriphos
20EC (62.23) and Phorate 10G (62.07 t/ha). Lowest yield $(58.67 \mathrm{t} / \mathrm{ha})$ was recorded in untreated check (Table 2). These results are in accordance with Pandey (2014) who reported higher cane yield in Chlorantraniliprole 0.4G; Padmasri et al. (2014) reported higher cane yield in Chlorantraniliprole 18.5 $\mathrm{SC}$.

The data collected at harvest have not indicated any significant difference in the quantitative yield parameters like height of cane, internode length, number of internodes per cane, girth of cane and single cane weight.The data collected at harvest on qualitative yield parameters like brix, sucrose, purity of juice and commercial cane sugar per cent were found non significant among the different treatments. The data pertaining to quality parameters like brix, sucrose, purity, commercial cane sugar per cent (CSS \%) varied from 20.10 (Control) to 21.87 (Chlorantraniliprole 0.4G), 20.00 (Control) to 20.66 (Chlorantraniliprole 0.4G), 90.67 (Control) to 96.95 (Fipronil 0.3G) and 14.03 (Control) to 14.92 (Chlorantraniliprole 18.5 SC), respectively (Table 3 and 4).

By working out the cost: benefit ratio, it was found 


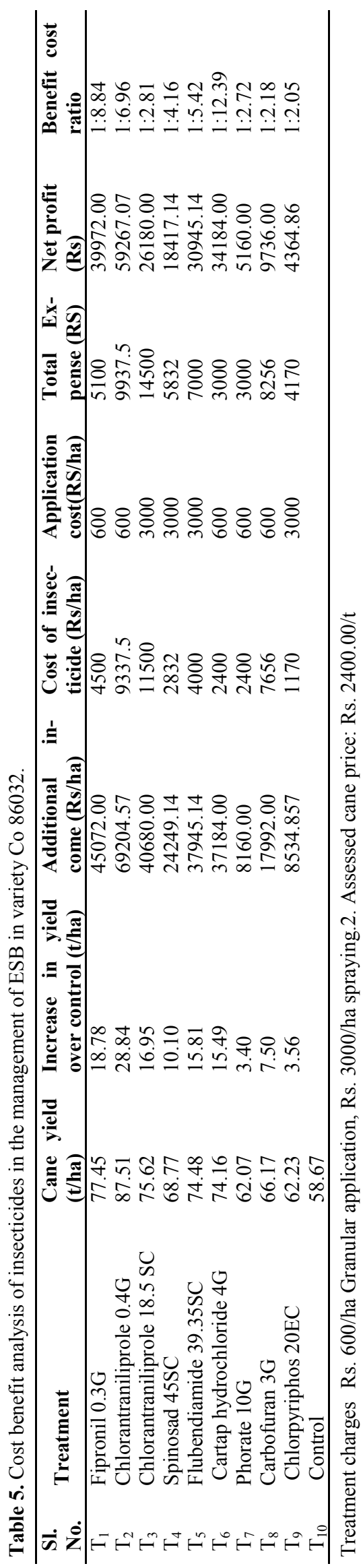

that Fipronil $0.3 \mathrm{G}$ registered highest cost: benefit ratio (1: 7.32) followed by Cartap hydrochloride 4G (1: 1.6.5), Chlorantraniliprole 0.4G (1: 5.68), Flubendiamide 39.35SC (1: 4.2), Phorate 10G (1: 3.33), Spinosad 45SC (1: 2.79), Chlorantraniliprole 18.5 SC (1: 2.33) and Chlorpyriphos 20EC (1: 2.31). However, Carbofuran $3 \mathrm{G}$ recorded the lowest cost: benefit ratio (1: 1.44) among the treatments (Table 5). Padmasri et al. (2014) who reported high B:C ratio with Flubendiamide 39.35SC and Spinosad 45SC. Chlorantraniliprole 18.5 SC has the highest cost than all other test insecticides but it gave the maximum per cent reduction of early shoot borer.

\section{Conclusion}

Studies on the bio-efficacy of different chemicals against $C$. infuscatellus on commercial sugarcane variety Co 86032 revealed that the Chlorantraniliprole $0.4 \mathrm{G}$ recorded lowest cumulative incidence and highest per cent reduction over the control which was followed by Cartap hydrochloride 4G, Chlorantraniliprole 18.5 SC, Flubendiamide 39.35SC and Fipronil $0.3 \mathrm{G}$ were found significantly superior in reducing the cumulative incidence of $C$. infuscatellus. In Co 86032 Cartap hydrochloride $4 \mathrm{G}$ was found to be the best insecticide in getting a highest cost benefit ratio (1:12.39). Other insecticides such as Fipronil $0.3 \mathrm{G}$ (1:8.84), Chlorantraniliprole $\quad 0.4 \mathrm{G} \quad(1: 6.96)$, Flubendiamide 39.35SC (1:5.42) and Spinosad 45SC (1:4.16) have also recorded better cost benefit ratio. Chlorantraniliprole 18.5 SC has the highest cost than all other test insecticides, but it gave the maximum reduction in early shoot borer infestation. Since Cartap hydrochloride $4 \mathrm{G}$ does not have crop label so we can recommend Fipronil $0.3 \mathrm{G}$ or Chlorantraniliprole $0.4 \mathrm{G}$ for the management of sugarcane early shoot borer.

\section{ACKNOWLEDGEMENTS}

The authors are thankful to the AICRP on sugarcane, at the Zonal agricultural research station, V.C farm, Mandya for providing all the facilities during the research work.

\section{REFERENCES}

Anonymous, (2015). Zonal Research and Extension Programme Workshop. University of Agriculture Sciences, Bangalore.

Avasthy, P.N. and Tiwari, N.K. (1986). The shoot borer, Chilo infuscatellus snellen. In: "Sugarcane Entomology in India" (Eds. David, H.S., Easwaramoorthy and Jayanthi, R.). Sugarcane Breeding Institute, Coimbatore, pp. 69-92.

Bhawar, N. Mohite, P. and Patil, S. (2016). Bioefficacy of new insecticide molecules against Sugarcane Early Shoot borer Chilo infuscatellus (Snellen) in Kolhapur Region of Maharashtra. J. Agr. Vet. Sci., 9(1): 32-35. 
H.G. Umashankar et al. / J. Appl. \& Nat. Sci. 10 (1): 434 - 438 (2018)

Gomez, K. A. and Gomez, A.A. (1984).Statistical Procedures for Agricultural Research with Emphasis on Rice. International Rice Research Institute, Los Banos, Philippines, pp. 268.

Hosmand, R.A. (1988). Statistical Methods for Agricultural Sciences. Timber press, Portland, Oregon, USA, pp. 405

Padmasri, A., Vidyasagar, G.E. and Bharathi, V. (2014). Evaluation of new molecules for management of stem borer on sugarcane. J. Agric. Vet. Sci., 7(6): $40-42$.

Pandey, S.K. (2014). Comparative efficacy of some insecticides on early shoot borer (Chilo infuscatellus Snellen) incidence in sugarcane under subtropical India.VEGETOS, 27(1): 146-148.

Patil, A.S. and Hapase, D.G.(1981). Research on sugarcane borers in Maharashtra. Proc. National Symp. on Stalk Borer, Karnal, pp.165-1758.

Sithanantham, S. (1973). Performance of some new organic insecticides in the control of sugarcane shoot borer Chilo infuscatellus snellen. Indian Sug.,22: 933-938.

Tukey, J.W. (1965). The technical tools of statistics. American Statistician, 19: 23-28. 